\title{
Investigating Validity of Math 105 as Prerequisite to Math 201 among Undergraduate Students, Nigeria
}

\author{
Yusuf F. Zakariya
}

Department of Science Education, Ahmadu Bello University, Zaria, Nigeria zafey23@yahoo.com

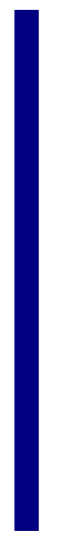

In this study, the author examined the validity of MATH 105 as a prerequisite to MATH 201. The data for this study was extracted directly from the examination results logic of the university. Descriptive statistics in form of correlations and linear regressions were used to analyze the obtained data. Three research questions were formulated and the collected data were analyzed using Minitab 16 statistical software. Some concepts of Graph theory were employed to answer one of the research questions and the other two using some statistical tools. The findings revealed that MATH 105 is a powerful predictor of students' performance in MATH 201. It then became obvious that a poor performance in MATH 105 is tantamount to a subsequent failure in MATH 201 while a good score in MATH 201 is a green light to passing MATH 201. Furthermore, it was recommended that MATH 105 should be retained and even thoroughly enforced as a prerequisite for MATH 201.

Keywords: prerequisite, graph, content validity, correlation, regression

\section{INTRODUCTION}

One of the important goals of curriculum development and evaluation at departmental level is to standardize and validate the prerequisite and corequisite courses in the institution. In Ahmadu Bello university, MATH 105-Differential and Integral Calculus has long been set as a prerequisite to passing MATH 201- Mathematical Methods I for undergraduate students of science education department, mathematics section. As an educator, it is of great concern to determine the significant effect or otherwise of MATH 105 on the performance of students in MATH 201. This is very crucial most especially now when the alarming rate of failure in mathematics attracts public attention (Ali, 2013; Olatunde, 2009; Salman, M.F., Mohammed, A.S., Ogunlade, A.A. and Ayinla, 2012).

Mathematics is simply a way of describing relationships between numbers and other measurable quantities. It can express simple equations as well as interactions among the smallest particles and the farthest objects in the known universe. Mathematics allows scientists to communicate ideas using universally accepted terminology(Zakariya\& Bamidele, 2015). The fantastic outcomes of mathematical findings on our everyday 
activities cannot be over-emphasized. In Ahmadu Bello University and most universities in Nigeria, MATH 201 is a mathematical method I that contains topics such as Limits, Continuity and Differentiability, Sequence and Series, Partial Derivatives, Differential Equations, etc. It is a 3-unit course that is compulsory and a prerequisite to most courses in the faculty of technology, physical sciences, environmental design and management such as building and mathematics education. This course is offered by the department of mathematics and computer science being taught by several lecturers every year. MATH 105 in parallel is a Differential and Integral Calculus course that contains mainly functions, differentiation of functions and some techniques of integration. It is a 2-unit course that is also compulsory and offered once in an academic year for undergraduate students. Despite the resources and the commitments of the department and the students to make MATH 201 a great one, the result is always woeful year in year out in virtually all the universities in Nigeria. In fact, Nigeria is facing the problem of poor performance in mathematics not only at university levels but also at all levels of education in the country(Georgewill, 1990; Obomanu \& Adaramola, 2011; Salman, M.F., Mohammed, A.S., Ogunlade, A.A. and Ayinla, 2012; Umar, Adamu, \& Sadiq, 2014; Zakariya \& Bamidele, 2015). This prompts some departments among other things especially science education to set MATH 105 as a prerequisite to passing MATH 201 for their students.

Studies on the predictive powers of prerequisite courses are scattered around the literature most especially outside the Nigerian domain. Researchers have studied some prerequisite changes in mathematics, its effects on students' performance and some methods of assessing these required skills (Evensky, Kao, Yang, Fadele, \& Fenner, 1997; Huang, O'shaughnessy, \& Wagner, 2005; Johnson \& Wang, 2012; Jones, Kouliavtsev, \& Ethridge, 2013; Ritchie, Rodriguez, Harrison, \& Wates, 2014). Lochet. al in (Loch, Jordan, Lowe, \& Mestel, 2013)investigated the effects of prerequisite calculus skills on the performance and perception of students using screencast method. Some other studies have also been reported on the automated review of prerequisite materials and the ill effects of lack of set theory as a relevant prerequisite for some college mathematics (Dogan-Dunlap, 2006; Levy, Shearer, \& Taylor, 2007).Unfortunately, most of these studies are either on different subjects other than mathematics or in countries other than Nigeria. After extensive and exhaustive search of the literature MATH 105 has never been validated as a prerequisite to MATH 201in any part of Nigeria despite its great importance to every academic planner. This present study was aimed at validating this prerequisite from both the content and the statistical point of views and thereby fills the gaps.

\section{SIGNIFICANCE OF THE STUDY}

This study was embarked upon to bring about progress in Mathematical Methods I. The findings of this study will help the departmental curriculum evaluators and academic monitory committee to determine whether to retain or discard MATH 105 as a prerequisite to MATH 201. Students' advisors will find this study very useful to predict the performance of their students in the target course from their results in the prerequisite course and thereby offer appropriate counseling. It would be very useful to school psychologists, university administrators, counsellors and educators who are 
concerned about the rising rate of low academic performance among Nigerian undergraduate students. This study being the first of its kinds will also serve as a reference material and thereby open doors for more researches in this approach.

\section{OBJECTIVES OF THE STUDY}

The objectives of this study were to:

i. Validate the contents of MATH 105 and MATH 201 by determining the connectivity between them.

ii. Determine the relationship between the performance of students in the prerequisite and target courses.

iii. Compare the performance of students that took the prerequisite course before taking the target course to that of the direct entry students that do not take the prerequisite.

\section{RESEARCH QUESTIONS}

Based on the aim and objectives of this study the following research questions were generated:

i. How connected are the contents of MATH 105 and MATH 201?

ii. Is there any relationship between the performance of students in the prerequisite course and the target course?

iii. What is the difference between the performance of students that took the prerequisite course before taking the target course and that of the direct entry students that do not take the prerequisite?

\section{METHODOLOGY OF THE STUDY}

This study was divided into three parts:

A.Connectivity between the two courses via content validation

B. Correlation and Regression Modeling

C. Comparison Modeling

In part $\mathrm{A}$, the connectivity between the target course and its prerequisite was investigated by constructively converting the contents of the courses to a graph. The vertices of this graph are the contents of the courses and there is an edge between any two distinct vertices if and only if one content is a necessary knowledge required in understanding the other. The connectivity of this graph was studied to establish how connected the contents of the target course and its prerequisite are.

In part B, when examining how well the MATH 105 is a valid predictor of a student performance in MATH 201 three possible measures of student course performance were considered out of which one was selected:
i. Points or scores
ii. Midterm grade
iii. Final grade 
The most common measure used is final grade. According to Keith, et. al in (Keith, W. and Michelle, 2013), the use of a final grade is attractive because final grades are accessible from a computer database. However, the difficulty associated with using final grades as criterion measure is that students who withdrawn may not be included in the analysis. For the purpose of the correlation involved in this study coupled with the fact that scores are parametric and readily retrievable from examination logic database the author decided to use the scores.

In part $\mathrm{C}$, the scores of students who took the prerequisite course before taking the target course was compared with that of the direct entry students using t-test.

\section{Sample and Sampling Procedure}

The target population for this study consisted of 472 undergraduate students in the department of science education, mathematics section at Ahmadu Bello University. This population was partitioned into 289 direct entry students (D.E) who were exempted from this perquisite course and 183 students (Jambites) who took the perquisite course. Meanwhile, 60 students from the first partition were selected for comparison modelling using t-test. Out of the remaining 183 students who offered MATH 105 and MTH 201 between 2007/2008 and 2012/2013 academic sessions, a sample of 60 students was selected for correlation and regression modelling see Figure 1.

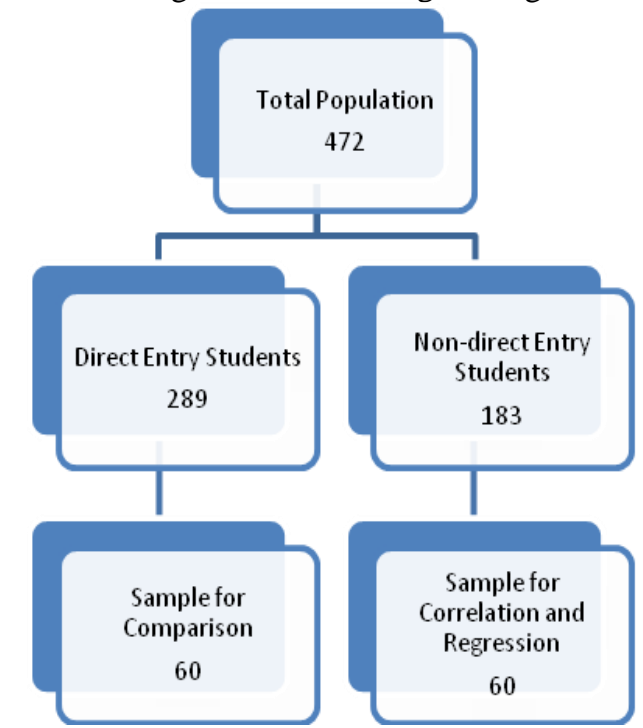

Figure 1: Sample and Sampling Procedure

The sampling was restricted to mathematics education students as they are the only students in the department of science education that offered MATH 105 as a prerequisite to MATH 201. This sample was selected through stratified random sampling procedure. The stratification spanned six academic sessions from 2007/2008 to $2012 / 2013$. The raw scores of the students were extracted from the examination logic data base. Then a juxtaposition of the scores in both courses was made by matching the 
scores in MATH 105 and the corresponding scores in MATH 201 in a tabular form. Table 1 shows the details of the perfect matching of the scores for both MATH 105 and MATH 201.

\section{Data Analysis and Instrumentation}

The data was analyzed using Minitab 16 statistical software. The correlation between the scores of the prerequisite and the target course was computed using Pearson correlation. Also, a regression analysis was carried out to determine how significant the contribution of MATH 105 was as a predicting factor of performance in MATH 201. Besides, t-test was adopted for the comparison modeling.

Table 1: Juxtaposition of Students' scores in MATH 105 and MATH 201 Exam

\begin{tabular}{|c|c|}
\hline MATH 105 & МATH 201 \\
\hline 60 & 56 \\
\hline 30 & 43 \\
\hline 24 & 18 \\
\hline 45 & 27 \\
\hline 55 & 40 \\
\hline 72 & 60 \\
\hline 50 & 40 \\
\hline 40 & 50 \\
\hline 50 & 48 \\
\hline 48 & 40 \\
\hline 50 & 40 \\
\hline 48 & 65 \\
\hline 48 & 44 \\
\hline 55 & 60 \\
\hline 43 & 40 \\
\hline 45 & 40 \\
\hline 48 & 42 \\
\hline 64 & 53 \\
\hline 62 & 43 \\
\hline 62 & 40 \\
\hline 72 & 55 \\
\hline 62 & 66 \\
\hline 53 & 60 \\
\hline 59 & 63 \\
\hline 83 & 40 \\
\hline 65 & 46 \\
\hline 78 & 48 \\
\hline 65 & 40 \\
\hline 73 & 42 \\
\hline 70 & 40 \\
\hline
\end{tabular}

\begin{tabular}{|c|c|}
\hline MATH 105 & МATH 201 \\
\hline 70 & 40 \\
\hline 65 & 40 \\
\hline 50 & 46 \\
\hline 58 & 40 \\
\hline 93 & 43 \\
\hline 73 & 66 \\
\hline 83 & 56 \\
\hline 90 & 59 \\
\hline 65 & 40 \\
\hline 85 & 40 \\
\hline 80 & 40 \\
\hline 50 & 17 \\
\hline 76 & 43 \\
\hline 41 & 46 \\
\hline 50 & 54 \\
\hline 61 & 44 \\
\hline 54 & 52 \\
\hline 45 & 59 \\
\hline 62 & 21 \\
\hline 42 & 15 \\
\hline 62 & 56 \\
\hline 63 & 60 \\
\hline 51 & 43 \\
\hline 60 & 64 \\
\hline 51 & 52 \\
\hline 62 & 62 \\
\hline 53 & 40 \\
\hline 54 & 70 \\
\hline 50 & 70 \\
\hline 73 & 72 \\
\hline
\end{tabular}

Source: Examination logic data base for science education department, $A B U$, Zaria.

\section{RESULTS AND DISCUSSION}

This section was divided into three parts based on the objectives of this study and a due consideration to answering the research questions. 


\section{Part A: Connectivity between the MATH 105 and MATH 201 via content validation}

In order to identify the necessary and appropriate knowledge or skills students need to possess prior to enrolling in a course the connectivity between the target course and the prerequisite should be validated. The following is the summarized contents of MATH 105 and MATH 201 respectively. I have only included here the abridged curriculum of the two courses in order to keep this article short.

Table 2: MATH 105 and MATH 201 abridged contents

\begin{tabular}{ll}
\hline$M A T H 105$ & $M A T H 201$ \\
\hline [1] Functions of a real variable & [4] Applications of Calculus \\
\hline [2] Differentiation & [5] Differential Equations \\
\hline [3] Integration & [6] Partial Differentiation \\
\hline
\end{tabular}

A graph $G$ is a nonempty set of finite elements $V$ called vertices together with a 2-element subset ${ }^{E}$ of $V$ called edges. There is an edge ${ }^{e}$ between two vertices $u$ and

$v_{\text {if }} e=u v$. If such ${ }^{e}$ exists between vertices $u$ and ${ }^{v}$ we say that the vertices are adjacent. A vertex is isolated if there is no edge joining it to another vertex in the graph. A graph $\mathrm{G}$ is said to be complete if there is an edge between every pair of its vertices. It is good to remark that a complete graph has the highest connectivity. For a good introductory book on graph theory see (Chartrand, Lesniak, \& Zhang, 2011; Wilson, 1998).

To investigate the connectivity we constructively convert the information in Table 2 to a graph denoted by C-graph. The vertices of C-graph are the contents [1] - [6] of Table 2 and there is an edge between any two distinct vertices if and only if one is a necessary knowledge required in understanding the other. See Figure 2

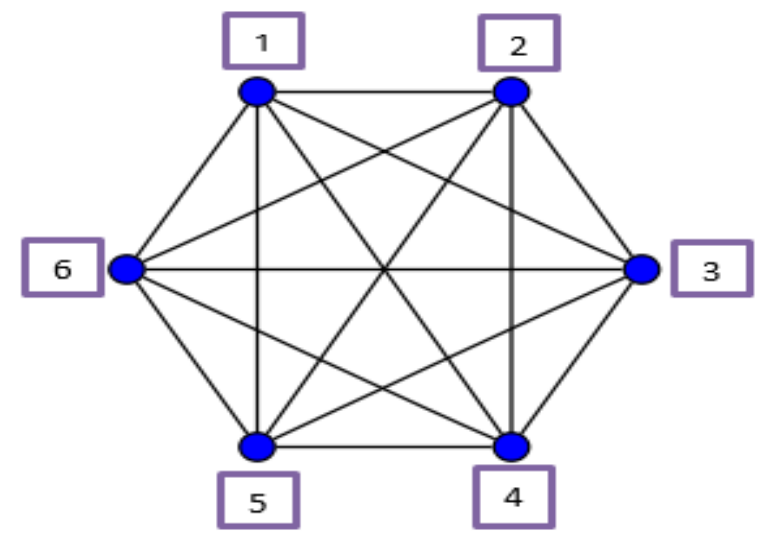

Figure 2: C-graph of the contents of MATH 105 and MATH 201 


\section{Research Question One}

- How connected are the contents of MATH 105 and MATH 201?

Following from the C-graph in Figure 1 it is clear that the graph is complete and every complete graph has the highest connectivity. In fact, to disconnect this graph one needs to remove all the vertices until only one vertex is left without edges. Therefore, there is a very strong connection between the contents of MATH 105 and the contents of MATH 201.

\section{Part B: Correlation and Regression Modelling}

Beyond contents validation additional evidence is required to ascertain whether or not students are likely to succeed in the target course unless the student has met the proposed prerequisite. The collected data in Table 1 was analysed using the instrument described under instrumentation. The following shows the correlation and regression outputs respectively from Minitab 16 statistical software.

Pearson correlation of MATH 201 and MATH $105=0.282$

P-Value $=0.029$

The regression equation is MATH $201=34.7+0.262 \mathrm{MATH} 105$

PredictorCoefSECoef $\mathrm{T} \quad \mathrm{P}$

Constant $34.671 \quad 7.106 \quad 4.880 .000$

MATH $105 \quad 0.2618 \quad 0.11692 .24 \quad 0.029$

$\mathrm{S}=12.6223 \quad \mathrm{R}-\mathrm{Sq}=8.0 \% \quad \mathrm{R}-\mathrm{Sq}(\operatorname{adj})=6.4 \%$

\section{Research Question Two}

- Is there any relationship between the performance of students in the prerequisite course and the target course?

To answer this research question the following hypotheses were generated:

HO: There is no significant relationship between the scores of students in MATH 105 and MATH 201

H1: The scores of students in MATH 105 significantly affect is related to the scores MATH 201.

Table 3 reveals that the Pearson correlation coefficient of MATH 105 on MATH 201 is 0.282 with P-value of $0.029(\ll<0.05)$ which is statistically significant at $\alpha=0.05$ level of significant. Hence, the null hypothesis $\mathrm{H} 0$ should be rejected and invariably the alternate hypothesis $\mathrm{H} 1$ should be accepted. Therefore, the scores of students in MATH 105 significantly affect positively the scores of students in MATH 201.

In order to examine the predict power of MATH 105 on the performance of students in MATH 201 liner regression analysis was carried. Our model in this case is;

MATH $201=B_{0}+B_{1}$ MATH 105 
Where $B_{0}$ is the intercept on the plane and $B_{1}$ is the regression coefficient that measures the expected change in MATH 201 when MATH 105 is changed. For this model the following hypotheses were formulated;
H0: $B_{1}=0$
$\mathrm{H} 1: B_{1} \neq 0$

Result from Table 4 reveals that $B_{1}=0.261$ and P-value of $0.029(\ll<<<0.05)$ which is statistically significant at $\alpha=0.05$ level of significant. Hence the null hypothesis H0 again should be rejected and invariably the alternate hypothesis $\mathrm{H} 1$ should be accepted. Therefore, a unit change in the scores of students in MATH 105 will significantly cause a change in the performance of students in MATH 201. Besides, Table 4 provides us the regression equation:

MATH $201=34.7+0.262$ MATH 105 (Equation 1)

This is a powerful tool in estimating the likely scores of students in MATH 201 from their performance in MATH 105.

\section{Part C: Comparison Modelling}

In order to completely validate the predictive power of MATH 105 on MATH 201 we set to compare the performance of students (Jambites) that took the prerequisite course before taking the target course to the direct entry (D.E) students that do not take the perquisite. The Table 5 shows the scores of 60 Jambites and 60 D.E students in MATH 201.

Table 3: Juxtaposition of Jambites and Direct Entry Students' results in MATH 201

\begin{tabular}{cc}
\hline JAMBITE & D.E \\
MATH 201 & MATH 201 \\
\hline 15 & 40 \\
\hline 17 & 40 \\
\hline 18 & 40 \\
\hline 21 & 40 \\
\hline 27 & 40 \\
\hline 37 & 40 \\
\hline 40 & 40 \\
\hline 40 & 40 \\
\hline 40 & 40 \\
\hline 40 & 40 \\
\hline 40 & 40 \\
\hline 42 & 41 \\
\hline 42 & 43 \\
\hline 43 & 43 \\
\hline 43 & 43 \\
\hline 43 & 45 \\
\hline 43 & 45 \\
\hline 43 & 47 \\
\hline 44 & 49 \\
\hline &
\end{tabular}

\begin{tabular}{|c|c|}
\hline $\begin{array}{l}\text { JAMBITE } \\
\text { MATH } 201\end{array}$ & $\begin{array}{c}D . E \\
M A T H 201\end{array}$ \\
\hline 51 & 10 \\
\hline 52 & 11 \\
\hline 52 & 11 \\
\hline 53 & 12 \\
\hline 54 & 14 \\
\hline 54 & 14 \\
\hline 54 & 15 \\
\hline 55 & 16 \\
\hline 56 & 17 \\
\hline 56 & 18 \\
\hline 56 & 19 \\
\hline 59 & 19 \\
\hline 59 & 20 \\
\hline 60 & 20 \\
\hline 60 & 20 \\
\hline 60 & 21 \\
\hline 60 & 22 \\
\hline 61 & 22 \\
\hline 61 & 23 \\
\hline
\end{tabular}




\begin{tabular}{ll}
\hline 44 & 50 \\
\hline 46 & 50 \\
\hline 46 & 51 \\
\hline 46 & 57 \\
\hline 48 & 57 \\
\hline 48 & 60 \\
\hline 49 & 62 \\
\hline 49 & 73 \\
\hline 50 & 74 \\
\hline 50 & 76 \\
\hline 51 & 85 \\
\hline
\end{tabular}

\begin{tabular}{cc}
\hline 62 & 23 \\
\hline 62 & 24 \\
\hline 63 & 40 \\
\hline 64 & 40 \\
\hline 65 & 40 \\
\hline 66 & 40 \\
\hline 66 & 40 \\
\hline 70 & 40 \\
\hline 70 & 40 \\
\hline 72 & 40 \\
\hline 72 & 40 \\
\hline
\end{tabular}

This date set in Table 3 was analyzed using Minitab 16 statistical software and the output is shown in Table 4. It is pertinent to remark that the same data for MATH 201 in Table 1 is repeated here while the only additional data is the scores for the direct entry students.

Table 4: Two-sample t-test JAMBITES vs D.E

\begin{tabular}{|c|c|c|c|}
\hline \multicolumn{4}{|c|}{$N$ Mean StDev SE Mean } \\
\hline JAMBITES & $\begin{array}{ll}60 & 50.2\end{array}$ & 13.0 & 1.7 \\
\hline D.E & $\begin{array}{ll}60 & 37.0\end{array}$ & 17.4 & 2.2 \\
\hline
\end{tabular}

Difference $=$ mu $($ JAMBITES $)-$ mu (D.E)

Estimate for difference: 13.13

95\% CI for difference: $(7.57,18.70)$

T-Test of difference $=0($ vs not $=)$ : T-Value $=4.68 \mathrm{P}-$ Value $=0.000 \mathrm{DF}=109$

\section{Research Question Three}

- What is the difference between the performance of students that took the prerequisite course before taking the target course and the direct entry students that do not take the prerequisite?

In order to answer this research question the following hypotheses were generated:

HO: There is no significant difference between the mean performance of Jambites and D.E students in MATH 201

H1: There is significant difference between the mean performance of Jambites and D.E students in MATH 201

Table 4 reveals the estimated difference between the mean scores of Jambites and D.E to be 13.13 and positive $t$-value of 4.68 . Since the P-value is $0.000(<<<<0.05)$ it follows that the mean difference is statistically significant. Hence the null hypothesis $\mathrm{H} 0$ should be rejected and invariably the alternate hypothesis $\mathrm{H} 1$ should be accepted. Therefore, there is a significant difference between the mean performance of Jambites and D.E students in MATH 201. Besides, as the difference $=$ mu (JAMBITES) - mu (D.E) is positive it can be deduced that the performance of students who took MATH 105 before taking MATH 201 is far better than the performance of the direct entry students who did not take MATH 105. 


\section{CONCLUSION}

In this study, MATH 105 was validated and identified as a necessary and adequate knowledge students must possess before proceeding to studying MATH 201. The contents connectivity of these two courses was investigated and found to be very strong. Further, it was established that MATH 105 is a powerful predictor of performance of students in MATH 201. In other words, a poor performance in MATH 105 is tantamount to subsequent failure in MATH 201 while a good score in MATH 201 is a green light to passing MATH 201. Therefore, all effort should be made to retain and not to discard MATH 105 as a prerequisite to MATH 201 among undergraduate students in Ahmadu Bello University.

\section{RECOMMENDATIONS}

Based on the findings of this study, the following were recommended:

1. The department of science education, Ahmadu Bello University, should retain and even thoroughly enforce MATH 105 as a prerequisite for MATH 201.

2. The mathematics students' advisor in the department of science education should consider equation 1 a tool for predicting students' performance in MATH 201. This will enhance proper monitoring of students' process and ease remedial counselling.

3. The direct entry students should be encouraged to at least audit MATH 105 if not taking it as a co-requisite course with MATH 201.

4. In future work, the prediction model can be improved upon by considering other parameters like age of the students, ethnicities, etc.

\section{REFERENCES}

Ali, H. (2013). Factors Affecting Students' Academic Performance in Mathematical Sciences Department in Tertiary Institutions in Nigeria. US-China Education Review A, 3(12), 905-913.

Chartrand, G., Lesniak, L., \& Zhang, P. (2011). Graphs \& Digraphs (Fifth Edit). Chapman \& Hall book.

Dogan-Dunlap, H. (2006). Lack of set theory relevant prerequisite knowledge. International Journal of Mathematical Education in Science and Technology, 37(4), 401-410. http://doi.org/10.1080/00207390600594853

Evensky, J., Kao, D., Yang, Q., Fadele, R., \& Fenner, R. (1997). Addressing prerequisite mathematics needs- a case study in introductory economics. International Journal of Mathematical Education in Science and Technology, 28(5), 629-639. http://doi.org/10.1080/0020739970280501

Georgewill, J. W. (1990). Causes of poor achievement in West African school certificate mathematics examinations in Rivers State secondary schools, Nigeria. International Journal of Mathematical Education in Science and Technology, 21(3), 379-385. http://doi.org/10.1080/0020739900210305 
Huang, J., O'shaughnessy, J., \& Wagner, R. (2005). Prerequisite Change and Its Effect on Intermediate Accounting Performance. Journal of Education for Business, 80(5), 283-288. http://doi.org/10.3200/JOEB.80.5.283-288

Johnson, M., \& Wang, J. (2012). A Method for assessing required course-related skills and prerequisite structure. ASEE Annual Conference and Exposition, Conference Proceedings, 3797(September). http://doi.org/10.1080/03043797.2014.960366

Jones, C. T., Kouliavtsev, M. S., \& Ethridge, J. R. (2013). Lower Level Prerequisites and Student Performance in Intermediate Business Courses: Does It Matter Where Students Take Their Principles Courses? Journal of Education for Business, 88(4), 238-245. http://doi.org/10.1080/08832323.2012.688777

Keith, W. and Michelle, R. (2013). Prerequisite Validation Study Examination of Reading as a Prerequisite to EMS-020. Office of Research and Planning, 12(2).

Levy, R., Shearer, M., \& Taylor, P. (2007). Automated Review of Prerequisite Material for Intermediate-Level Undergraduate Mathematics. Primus, 17(2), 167-180. http://doi.org/10.1080/10511970601131555

Loch, B., Jordan, C. R., Lowe, T. W., \& Mestel, B. D. (2013). Do screencasts help to revise prerequisite mathematics? An investigation of student performance and perception. International Journal of Mathematical Education in Science and Technology, 45(2), 256-268. http://doi.org/10.1080/0020739X.2013.822581

Obomanu, B. J., \& Adaramola, M. O. (2011). Factors Related to Under Achievement in Science, Technology and Mathematics Education (STME) in Secondary Schools in Rivers State, Nigeria. World Journal of Education, 1(1), 102-109. http://doi.org/10.5430/wje.v1n1p102

Olatunde, Y. P. (2009). Mathematics Anxiety and Academic Achievements in Some Selected Senior Secondary Schools in Southwertern Nigeria. Pakistan Journal of Social Sciences, 6(3), 133-137.

Ritchie, C. M., Rodriguez, L. C., Harrison, D. S., \& Wates, K. W. (2014). The Impact of Prerequisite General Education Courses on the ETS Major Field Test for Business (MFT-B). Journal of Education for Business, 89(6), 292-299. http://doi.org/10.1080/08832323.2014.889065

Salman, M.F., Mohammed, A.S., Ogunlade, A.A. and Ayinla, J. O. (2012). Causes of Mass Failure in Senior School Certificate Mathematics Examinations As Viewed By Secondary School Teachers and Students in Ondo , Nigeria . Journal of Education and Practice, 3(8).

Umar, T., Adamu, A., \& Sadiq, A. M. (2014). The Causes of Poor Performance in Mathematics among Public Senior Secondary School Students in Azare Metropolis of Bauchi, 4(6), 32-40.

Wilson, R. J. (1998). Introduction to Graph Theory (Fourth Edi). Longman.

Zakariya, Y. F., \& Bamidele, E. F. (2015). Investigation into the Causes of Poor Academic Performance in Mathematics among Nigerian Undergraduate Students, 1(1), 1-5. http://doi.org/10.12691/wjssh-1-1-1 


\section{Turkish Abstract}

\section{Math 105'in Math 201'e Önkoşul Olmasının Geçerliğinin Lisans Öğrencileri Arasında İncelenmesi, Nijerya}

Bu çalışmada Math 105'in Math 201 dersine önkoşul olmasının geçerliğini belirlemek amaçlanmıştır. Çalışmanın verileri üniversiteden elde edilen sınav sonuçlarından direkt olarak elde edilmiştir. Elde edilen verileri analiz etmede korelasyon ve linear regresyon olarak betimleyivi istatistikler kullanılmıştır. Üç araştırma sorusu formüle edilmiş ve toplanan veri Minitab 16 istatik programı kullanılarak analiz edilmiştir. Araştırma sorularından birini cevaplamak için çizge kuramının bazı kavramları, diğer iki soru için bazı istatiki araçlar kullanılmıştır. Bulgular Math 105'in öğrencilerin Math 201 performanslarının güçlü bir yordayıcıs1 olduğunu göstermiştir. Math 105 dersindeki zayıf performans Math 201'deki başarısızlıkla aynı anlama geldiği ve Math 105 'den iyi bir puanın da Math 201'I geçmek için yeșil ıșık anlamına geldiği ortaya çıkmıștır. Dahası, Math 105 dersinin alınması hatta Math 201 dersi için bir ön koşul olması gerektiği önerilmiştir.

Anahtar Kelimeler: önkoşul, çizge, içerik geçerliği, korelasyon, regresyon

\section{French Abstract}

En examinant Validité de Maths 105 comme Prérequis à Maths 201 parmi étudiants en licence, le Nigeria

Dans cette étude, l'auteur a examiné la validité de MATHS 105 comme un prérequis aux MATHS 201. Les données pour cette étude étaient extracteddirectly de la logique de résultats d'examen de l'université. La statistique descriptive en formulaire de corrélations et des régressions linéaires a été utilisée pour analyser les données obtenues. Trois questions de recherche ont été formulées et les données rassemblées ont été analysées utilisant la Miniétiquette 16 logiciel statistique. Quelques concepts de Théorie des graphes ont été employés pour répondre à une des questions de recherche et la deux autre utilisation quelques outils statistiques. Les découvertes ont révélé que les MATHS 105 sont un prophète puissant de la performance des étudiants dans des MATHS 201. Il est alors devenu évident qu'une performance faible dans des MATHS 105 est équivalente à l'échec ultérieur dans des MATHS 201 tandis qu'un bon score dans des MATHS 201 est un feu vert au passage de MATHS 201. En outre, on l'a recommandé que les MATHS 105 doivent être conservées et faites même à fond respecter comme un prérequis pour des MATHS 201.

Mots Clés: le prérequis, le graphique, contente la validité, la corrélation, la regression

\section{Arabic Abstract}

التحقيق صلاحية MATH 105 كثرط مسبق لـ MATH 201 بين طلاب المرحلة الجامعية في نيجيريا

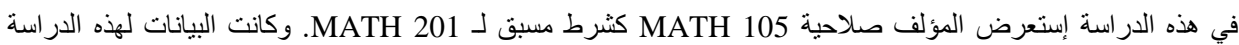

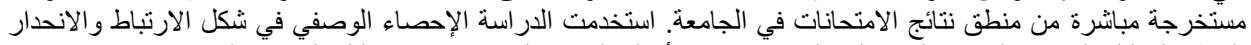

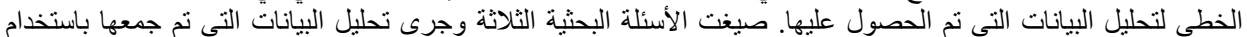

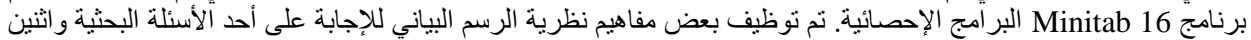

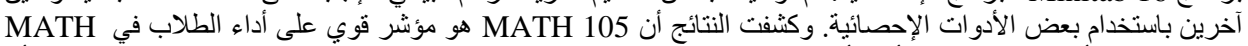

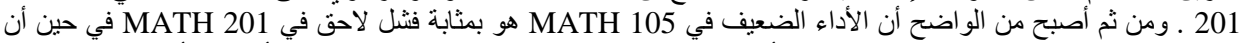

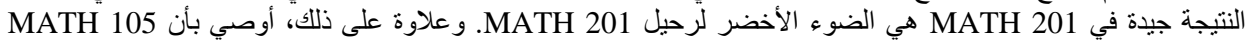

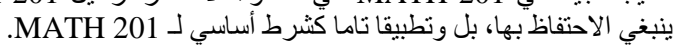

$$
\text { كلمات البحث: شرط أساسي، الرسم البياني، صلاحية المحتوى، الارتباط، الانحدار }
$$

